\title{
THE EFFECT OF (Treculia Africana) AFRICAN BREADFRUIT ON SERUM ELECTROLYTE ENZYME AND SOME HAEMATOLOGICAL PARAMETER IN RAT: A SUB-CHRONIC STUDY
}

\author{
O. O OKWARI, E.E. EDET AND F. E.UBOH
}

(Received 18 January 2010; Revision Accepted 24, March 2010)

\begin{abstract}
A sub-chronic effect of diet of Treculia africana (Bread fruit BF) on serum electrolyte, enzyme and some haematological parameters in rats was studied. The test-diets were administered for 21 days after which, serum electrolyte enzyme and heamatological parameters were assayed. The control group were similarly treated but given normal diet The result showed that serum sodium $(\mathrm{Na}+)$ of rats given bread fruit diet of $10 \%$ and $20 \%$ respectively were significantly $(P<0.001)$ and $P<0.05)$ lower, but significantly $(P<0.00)$ higher for those given $B F$ of $100 \%$ when compared with control. The potassium and chloride ion levels in test and control groups were not significantly different. Calcium ion levels in the animals $10 \%$ and $20 \%$ respectively were not significantly different but the $\mathrm{Ca}^{2+}$ levels in those given BF 100\% was significantly $(P<0.01)$ lower compared with control. The bicarbonate ion levels were significantly $(P<0.01)$ higher in test than control. Serum levels of ALT and ALP were significantly $(P<0.001)$ higher in test than the control. The AST levels in animals given $10 \%$ and $20 \%$ BF were not significantly different but those given BF $100 \%$ was significantly $(P<0.001)$ higher compared with control. The breadfruit diet when consumed without enriching food supplement decreased $\mathrm{RBC}, \mathrm{HB}, \mathrm{PCV}, \mathrm{MCHC}$ indicating microcytic hypo-chronic anaemia and possible hepato cellular damage as shown in increase liver enzymes.
\end{abstract}

KEY WORD: Bread Fruit, enzyme, blood parameter and rats.

\section{INTRODUCTION}

African breadfruit (Treculia Africana Decne Var Africana) family Moraceae is one of the four members of the genera Treculia found in many parts of West and Tropical Africa around evergreen and deciduous forest, by streams and sometimes planted (Hutchison et al, 1958; Woodland, 1991). In Nigeria it is very common in the West and Eastern States. Treculia africana is an unbuttressed large tree $24-37 \mathrm{~m}$ high with fluted bole up to $3 \mathrm{~m}$ in girth. The fruits are yellow and spongy in texture up to $45.72 \mathrm{~cm}$ inches in diameter and containing many small seeds $1.27 \mathrm{~cm}$ long like orange-pips embebed in various depths in meshy elongated bract (Irvine, 1961).

Some of the local names of breadfruit in Nigeria are Yorubas - ofon; Benis - Ize; Igbos - Ukwa; Hausa barafuta; Efik/lbibios/Anangs called it ediang. The Ashanti in Ghana called it totin (Keay et al, 1964). Breadfruit seed have groundnut flavour when toasted; sometimes they are made into refreshing drinks or used as soup condiments or thickening, breadfruit cakes, snacks and cockies (Irvine, 1961). There is scanty literature on breadfruit. Edet and his colleages (1982) reported on the proximate fatty acid composition and nutritional value of the seeds and Akubor (1997) reported on the seed composition, while Okwari et al, (2007) reported on the antihistaminergic activity of the breadfruit seed diet on gastric acid secretion in rat.

It is a scientific knowledge that many substances taken into the body influence secretion and excretion of electrolyte and blood cell production. There have not been reports on how breadfruit affects serum electrolytes, enzyme and its impact on haematological parameters. The aim of this study is to find out the effect of breadfruit diet on electrolyte and enzyme profile and some haematological parameters in rats.

\section{MATERIALS AND METHOD} Animals

Albino Wistar rats $(120-180 \mathrm{~g})$ from the Department of Physiology, Faculty of Basic Medical Sciences, University of Calabar, Nigeria were randomly assigned into four groups of 6 rats in cages and maintained under standard laboratory conditions of humidity and temperature $28^{\circ} \mathrm{C}$ and 12 hour light and dark cycle. They were fed with rat chow and allowed drinking water for seven days before the start of the experiment. At the start of the experiment, group 1 received standard diet for 21 days and serves as control, Group II, III and VI received 10\%, 20\% and $100 \%$ breadfruit diet respectively and also for 21 days. The feeding regiment and cleaning were done daily between the hours of 9am and 10am. At the end of the study the animals were sacrified by an overdose of either and chloroform mixture and the blood was obtained by cardiac puncture. The obtained blood samples were stored in EDTA bottle and in plain sample ottle for serum and used for electrolyte and some enzymes assay and haematological findings.

O. O. Okwari, Department of Physiology, Faculty of Basic Medical Sciences, University of Calabar - Calabar, Nigeria

E.E. Edet, Department of Biochemistry, Faculty of Basic Medical Sciences, University of Calabar - Calabar, Nigeria

F. E. Uboh, Department of Biochemistry, Faculty of Basic Medical Sciences, University of Calabar - Calabar, Nigeria 


\section{Preparation of Breadfruit Diet}

The breadfruit was purchase in Calabar, Cross River State and was identified in the Department of Botany, University of Calabar, Nigeria. The fruit was fermented and the seeds were freed from the slimy meshy mass and washed. The seed $1.5 \mathrm{~kg}$ were then boiled for a few minutes 10 minutes and then transfer to a drying oven (Astell Hearson, England) set at $60^{\circ} \mathrm{C}$. The dried fruits $(1.2 \mathrm{~kg})$ were blended to power using (Philip Blender/Grinder England).

Table I: The composition of standard diet and test are as shown

\begin{tabular}{|l|l|l|l|l|}
\hline Mineral content & $\begin{array}{l}\text { Group I } \\
\text { Control }\end{array}$ & $\begin{array}{l}\text { Group II } \\
10 \% \text { BF }\end{array}$ & $\begin{array}{l}\text { Group III } \\
20 \% \text { BF }\end{array}$ & $\begin{array}{l}\text { Group IV } \\
100 \% \text { BF }\end{array}$ \\
\hline Corn starch & 150.00 & 150 & 150 & - \\
\hline African breadfruit & - & 100 & 200 & 1000 \\
\hline Casilan & 100.00 & & & - \\
\hline Sucrose & 571.00 & 470 & 470 & - \\
\hline Glucose & 50.00 & 50.00 & 50.00 & - \\
\hline Corn oil & 50.00 & 50 & 50 & - \\
\hline Cellulose & 18.00 & 80 & 80 & - \\
\hline Mineral mixture & 40 & 40 & 40 & - \\
\hline Vitamin mixture & 10 & 10 & 10 & - \\
\hline Total & 1000 & 1000 & 1000 & 1000 \\
\hline
\end{tabular}

Source: ICN Biochemical 1996.

Table 2: Composition of mineral and vitamin mixture

\begin{tabular}{|l|l|l|l|}
\hline Mineral oil composition & Mg/100g & Vitamin mixture & Mg/kg \\
\hline $\mathrm{Ca}^{2+}$ phosphate dibasic & 500 & Thiamine hydrochloride & $600 \mathrm{mg}$ \\
Sodium chloride & 74 & Riboflavin & $600 \mathrm{mg}$ \\
Potassium chloride & 220 & Pyrodoxin HCl & $700 \mathrm{mg}$ \\
Potassium sulphate & 52 & Nicotinic acid & $3 \mathrm{mg}$ \\
Magnesium oxide & 24 & D-Ca ${ }^{2+}$ panthothenate & $1.6 \mathrm{mg}$ \\
Maganous carbonate & 3.50 & Folic Acid & $200 \mathrm{mg}$ \\
Fenic citrate & 6 & D-Biotin & $20 \mathrm{mg}$ \\
Zinc carbonate & 1.6 & Cynocobolamine & $1.0 \mathrm{mg}$ \\
Potassium iodate & 0.01 & Vitamin D-3 & $200 \mathrm{mg}$ \\
Sodium selemite & 0.01 & Vitamin K & $50 \mathrm{mg}$ \\
Chronum potassium & 0.55 & & \\
Cupric carbonate & 0.30 & & \\
\hline
\end{tabular}

Source: ICN Biochemical 1996* For Vit. Mixture riboflavin was added last and was thoroughly mixed to allow uniformity.

\section{Electrolyte assay}

The assay of sodium $\left(\mathrm{Na}^{+}\right)$potassium $\left(\mathrm{K}^{+}\right)$ calcium $\left(\mathrm{Ca}^{2+}\right)$ was carried out using flame photometer (Petracourt model 410c England) while the chloride $\left(\mathrm{Cl}^{-}\right)$ and Bicarbonate $\left(\mathrm{HCO}_{3}{ }^{-}\right)$meter were used to determine these anions in the University of Calabar Teaching Hospital, UTCH, Calabar.

\section{Haematology}

The red blood cell and platelets counts were carried out by the method described by Baker, et al (1998). The improved neubauer was charge with 1:200 dilution and the cells were counted in 80 small squares, observing strictly the margin rule. Haemoglobin $(\mathrm{Hb})$ content was done by cyanmethaemoglobin (Baker and Silverton, 1985). The result of RBC, Hb and PCV were employed for the determination of absolute value as described by (Baker and Silverton, 1985).

\section{Statistical Analysis}

The results were analysed by one way analysis of variance (ANOVA) followed by student $t$-test to evaluate the significance of difference between the mean values of measured parameters in respect of test and control groups. A significant difference was accepted at $\mathrm{P}<0.05$.

\section{RESULTS}

The serum electrolytes (Table 1) shows that sodium $\left(\mathrm{Na}^{+}\right)$levels of control, at $10 \%, 20 \%$ and $100 \%$ $\mathrm{BF}$ meal. The result show that the serum $\mathrm{Na}^{+}$levels of animals fed with $10 \%$ and $20 \% \mathrm{BF}$ respectively were significantly $(P<0.001)$ and $(P<0.05)$ lower but the $\mathrm{Na}^{+}$ levels in the $100 \%$ BF meal was significantly $(P<0.001)$ higher compared with control. The potassium levels in test and control were not significant different. The calcium levels in control BF $10 \%$, BF $20 \%$ and BF $100 \%$ were shown in the table respectively. Both $\mathrm{BF} 10 \%$ and BF $20 \%$ were not significantly different but the BF $100 \%$ was significantly $(P<0.01)$ lower compared with control. The bicarbonate $\left(\mathrm{HCO}_{3}^{-}\right)$ion level were significantly $(\mathrm{P}<0.001)$ higher in test than control while the chloride $\left(\mathrm{Cl}^{-}\right)$ion levels were not significantly different.

Table 2 shows the results of serum enzymes: ALT, AST, ALP and the ratio of AST/ALT for control, BF $10 \%$, BF $20 \%$ and BF $100 \%$ groups. Both ALT and ALP were significantly $(P<0.001)$ higher than control. The AST level were see table respectively. The AST levels in BF $10 \%$ and BF $20 \%$ had no significant differences 
but BF $100 \%$ was significantly $(P<0.001)$ higher than control.

The result of the haematolgoical studies showed that the RBC, platelets and $\mathrm{Hb}$ for control $\mathrm{BF} 10 \%, \mathrm{BF}$ no significant differences when compared with control. But $\mathrm{MCH}$ and $\mathrm{MCHC}$ were significantly lower $(\mathrm{P}<0.01)$ when compared with control.

Table 1: Serum electrolytes in Breadfruit diet fed rats (mmol/L)

\begin{tabular}{|l|l|l|l|l}
\hline & Control & BF $10 \%$ & BF $20 \%$ & BF $(100 \%)$ \\
$\mathrm{Na}^{+}$ & $144.83 \pm 0.43$ & $141.00 \pm 0.49^{* * *}$ & $142.00 \pm 0.97^{*}$ & $148.67 \pm 0.46^{* *}$ \\
$\mathrm{~K}^{+}$ & $5.11 \pm 0.02$ & $5.25 \pm 0.27^{\mathrm{NS}}$ & $4.65 \pm 0.27^{\mathrm{NS}}$ & $5.10 \pm 0.15^{\mathrm{ns}}$ \\
$\mathrm{HCO}_{3}$ & $24.33 \pm 0.36$ & $26.33 \pm 0.37^{* *}$ & $26.83 \pm 0.77^{*}$ & $26.67 \pm 0.49^{* *}$ \\
$\mathrm{Cl}^{-}$ & $101.67 \pm 0.83$ & $100.50 \pm 0.37^{\mathrm{NS}}$ & $104.00 \pm 1.89^{\mathrm{NS}}$ & $100.50 \pm 0.37^{\mathrm{NS}}$ \\
\hline
\end{tabular}

Values in $\mathrm{X} \pm \mathrm{SEM} ; \mathrm{n}=6 ; \mathrm{NS}=$ not statistically significant;

${ }^{*}=(\mathrm{P}<0.05) ;{ }^{* *}=(\mathrm{P}<0.01) ;{ }^{* *}=(\mathrm{P}<0.001)$ compared to control.

$\mathrm{BF}=$ Breadfruit.

Table 2:Serum enzymes in breadfruit fed rats ( $\mathrm{mmol} / \mathrm{L})$

\begin{tabular}{|l|l|l|l|l}
\hline Enzymes & Control & BF $10 \%$ & BF $20 \%$ & BF $(100 \%)$ \\
ALT & $36.50 \pm 1.71$ & $51.33 \pm 2.49^{\star * *}$ & $52.33 \pm 2.85^{\star *}$ & $51.00 \pm 1.47^{* * *}$ \\
AST & $60.17 \pm 2.05$ & $60.00 \pm 1.95^{\mathrm{NS}}$ & $60.00 \pm 1.95^{\mathrm{NS}}$ & $68.50 \pm 2.20^{*}$ \\
ALP & $342.60 \pm 2.59$ & $379.90 \pm 6.96^{* *}$ & $374.85 \pm 5.95^{\star *}$ & $429.80 \pm 5.07$ \\
AST:ALT & 1.65 & 1.17 & 1.15 & 1.34 \\
ratio & & & & \\
\hline
\end{tabular}

- Value in $\mathrm{X} \pm \mathrm{SEM}^{*}=(\mathrm{P}<0.05) ;{ }^{* *}=(\mathrm{P}<0.01) ;{ }^{* * *}=(\mathrm{P}<0.001)$

compared to control $n=6$; NS = not statistically significant;

$\mathrm{BF}=$ Breadfruit

Table 3: Effect of breadfruit diet on some haematolgoical parameters

\begin{tabular}{|c|c|c|c|c|}
\hline Parameters & Control & $10 \% \mathrm{BF}$ & $20 \% \mathrm{BF}$ & $(100 \%) \mathrm{BF}$ \\
\hline $\begin{array}{l}\mathrm{RBC} \\
\text { cell/L) }\end{array}$ & $7.13 \pm 0.07$ & $6.67 \pm 0.13^{*}$ & $6.66 \pm 0.14^{*}$ & $5.98 \pm 0.21^{* * *}$ \\
\hline $\begin{array}{l}\text { Platelets } \\
10^{3} \text { cell } / \mathrm{mm}^{3}\end{array}$ & $125.8 \pm 1.68$ & $61.67 \pm 1.83^{* *}$ & $77.08 \pm 2.28^{* *}$ & $96.6 \pm 2.71^{* * *}$ \\
\hline $\mathrm{Hb}(\mathrm{g})$ & $14.47 \pm 0.15$ & $12.32 \pm 0.19^{* *}$ & $12.32 \pm 0.19^{* *}$ & $12.68 \pm 0.44^{* *}$ \\
\hline PCV (\%) & $45.75 \pm 0.72$ & $45.17 \pm 0.82^{N S}$ & $44.17 \pm 0.52^{N S}$ & $43.83 \pm 0.87^{\mathrm{NS}}$ \\
\hline MCV (fl) & $64.24 \pm 0.41$ & $66.48 \pm 0.76^{\mathrm{NS}}$ & $65.59 \pm 0.94^{\mathrm{NS}}$ & $69.45 \pm 1.15^{\mathrm{NS}}$ \\
\hline $\mathrm{MCH}(\mathrm{pg})$ & $20.23 \pm 0.09$ & $17.92 \pm 0.72^{*}$ & $17.74 \pm 0.24^{* *}$ & $21.82 \pm 0.49^{*}$ \\
\hline $\mathrm{MCHC}(\%)$ & $31.64 \pm 0.26$ & $27.23 \pm 1.27^{\star *}$ & $26.69 \pm 6.69^{* * *}$ & $30.40 \pm 0.13^{* *}$ \\
\hline
\end{tabular}

Value are in $\mathrm{X} \pm$ SEM, $\mathrm{n}=6 ;^{*}=(\mathrm{P}<0.05) ;{ }^{* *}=(\mathrm{P}<0.01)$ and

${ }^{* * *}=(P<0.001)$; compared to control NS = not statistically significant; BF = Breadfruit 


\section{DISCUSSION}

The serum sodium $\left(\mathrm{Na}^{+}\right)$levels in $10 \%$ and $20 \%$ bread fruit fed animals were significantly $(P<0.001$ and $P<0.05)$ lower but was significantly $(P<0.001)$ higher in those fed with $100 \%$ bread fruit compared with control. This suggest that $100 \%$ bread fruit may attribute to the changes in levels of sodium. It has been reported that sodium imbalance may result from a loss or gain of sodium, or from a change in water volume as sodium affect body water distribution, maintain acid-base balance as well as influence chloride and potassium levels (Loeb et al, 2005). The potassium $\mathrm{K}$ levels were not significantly different in all the groups depicting equilibrium between the intracellular compartment. Potassium is vital to homeostasis. The major force maintaining the difference in cation concentration between the intracellular fluid and the extra cellular fluid is the activity of sodium potassium pump intergral to all cell membrane (Field et al 2006) this may explain the seeming difference in the breadfruit diet.

The calcium ion levels were not significantly different in $10 \%$ and $20 \%$ groups but were significantly $(P<0.05)$ lower in $100 \% \mathrm{BF}$ fed group. Breadfruit is rich in phosphate (Edet et al, 1982). The lower and the non - significance in calcium level may be due in part to intracellular adjustment, buffering and metabolic activity with phosphate present in breadfruit, although the phosphate level was not measured. The bicarbonate $\left(\mathrm{HCO}_{3}^{-}\right)$ion levels were significantly higher in test groups than control groups while the chloride $\left(\mathrm{Cl}^{-}\right)$ion level were not significantly different in the test and control groups. These ion levels among other events are responsible for the acid-base balance (Sembulingam and Sembulingam, 2007). Increase $\mathrm{HCO}_{3}^{-}$ion may be due to acute or chronic alkalosis (Edwards et al, 1996). The chloride and bicarbonate exchanger protein in the cell membrane is said to mediate the simultaneous movement of these two ions in opposite direction (Nelson and Cox, 2005). There exist an inverse relationship between the plasma $\mathrm{Cl}^{-}$concentration and the rate at which the filtered $\mathrm{HCO}_{3}^{-}$is reabsorbed. The mechanism of this reciprocal relation is not well known. But one explanation may be the existence of the well known chloride shift in response to changes in $\mathrm{HCO}_{3}^{-}$to maintain the electrical neutrality between plasma and cell compartment. So as a consequence of the reciprocal relationship as plasma $\mathrm{HCO}_{3}^{-}$concentration rises, $\mathrm{Cl}^{-}$concentration in the plasma falls. This inverse relationship serves to maintain the sum of the plasma concentration of $\mathrm{HCO}_{3}^{-}$and $\mathrm{Cl}^{-}$constant (Nelson and Cox, 2005).

The ALT and ALP levels in the test groups were significantly $(P<0.001)$ higher compared with control. But the AST levels were not significantly different in $10 \%$ and $20 \%$ groups but was significantly higher in $100 \% \mathrm{BF}$ fed compared with control. Elevation of liver enzymes in serum are mostly associated with liver damage and the activities of either ALT or AST or both are often considered together (Chapman et al, 2006; Loeb et al, 2005). It has been hypothetised that in cardiac disorders, there is always a noticeable change in the levels of cardiac specific enzymes such as the amino transferases. Stroeve and Makarova (1984) reported that a high AST: ALT ration indicate pathology involving the heart and the reverse of this ratio points to the liver. hepatocellular injury such as active cirrhosis or drug induced hepatisis. Moderate rise in ALP are said to reflect biliary obstruction (Loeb et al, 2005).

The effect of breadfruit ingested for 21 days on haematolgoical parameter showed a reduction of RBC count when compared with the control (although within normal physiological ranges). This indicates that breadfruit has some mild influence in haemopoeisis, although the mechanisms were not investigated. Red blood cells transport oxygen to cell by haemoglobin $(\mathrm{Hb})$ (Ganong, 2005; Guyton and Hall, 2000). The Hb content of the breadfruit fed rats was also significantly reduced. The reduction may be due to the decrease RBC count and possibly the mineral content of breadfruit. It may be that breadfruit has little iron content required for the $\mathrm{Hb}$ elevation in blood. The PCV of the breadfruit fed rats was not significantly different from the control. PCV is a measure of the number and size of the red blood cells (Lewis et al, 2002). The result indicates a reduction in number of RBC with corresponding decrease in size of the RBCS. This confirmed by the non-significant differences in the MCV. This may be due to the decreases in $\mathrm{Hb}, \mathrm{PCV}$ and RBCs. Both $\mathrm{MCH}$ and $\mathrm{MCHC}$ were reduced significantly as result of the reduction of $\mathrm{Hb}, \mathrm{PCV}$ and RBCS. Reduced $\mathrm{MCHC}$ indicates iron deficiency characterized by low PCV, $\mathrm{Hb}$ and RBC (Ganong, 2002; Cheesbrough, 2005).

Thrombocytopenic effect was observed in the test groups. The possible cause of the depressed platelet production may be diminished megakaryocytes resulting from ingestion of breadfruit (Guyton and Hall, 2001). Edet et al (1982) reported that breadfruit has low nutritional value.

In conclusion, whole breadfruit consumption may lead to increase in sodium serum level. It is known that in some diseases that affect the heart, liver and kidney, a train of events that set in often manifest clinical features of hypervolaemia. Volume expansion in some common systemic disease is associated with sodium and fluid overload resulting largely due to secondary responses to circulatory insufficiency associated with primary disorder (Field et al, 2006). The increase in serum enzyme points to possible hepatrophy, while decrease in RBC, $\mathrm{Hb}$ and $\mathrm{MCHC}$ points to possible microcytic hypochronic anaemia. Hence, the consumption of breadfruit should be highly regulated.

\section{REFERENCES}

Akubori, J. P., 1997. Proximate composition and selected functional properties of African breadfruit and sweet potato flow blend plant food. London Press. Pp. $140-142$.

Chapman, R.W; Collier, J.P; Hayes, P.C., 2006. Liver and lalliary tract disease. In: Boon NA, Colledge NR, Walker BR (eds.) Davidison's Principles and Practice of Medicine (20 $0^{\text {th }}$ edition). Churchill Livingstone. Section 23 p. 940.

Cheebrough, M., 2006. District laboratory practice in Tropical countries Part 2. Cambridge University Press. P. 313. 
Edet E.E, Eka O.U, Ifon, E.T., 1984. Chemical evaluation of nutritive value of seeds of African breadfruit (Treculia africana). Food Chemistry, $17: 41-47$.

Edward C.R.W, Brouchier, I.A.D, Haslett, C, Chilvers, E.R., 1996. Davidson's Principle and Practice of Medicine. Churchill Livingstone. Pp. 590 - 591.

Field, M. J; Burnett, L., Sullivan, D.R., Stewart, P., 2006. Clinical biochemistry and metabolism. In Boon NA, Colledge NR, Walker BR (eds.) Davidison's Principles and Practice of Medicine $\left(20^{\text {th }}\right.$ edition). Churchill Livingstone Toronto, P426.

Ganong, W.F., 2005. Review of Medical Physiology. $22^{\text {nd }}$ edition. McGraw-hill. P. $667-69$.

Gaspard, J.D., 2002. The red blood cell and alteration in oxygen transport: In Pathophysiology Concept of altered health state. Porth $\mathrm{CM} 6^{\text {th }}$ edn. Lippincot Williams and Wilkin, Philadelphia. $\mathrm{P}$ 280.

Guyton, A.C. and Hall, J.E., 2000. A Textbook of Medical Physiology $\left(10^{\text {th }}\right.$ edn $)$. WB Saunders. Philadelphia. P. $426-427$.

Hutchinson, J., Dalziel, J.M. and Keay, R.W.J., 1958. Flora of West Tropical Africa 1 \& 2 pp. 13, 302. Irvine FR (1961). Woody plants of Ghana with special references to uses. P. 398, $449-450$.
Keay, R. W. J., Onochie, C.F.A. and Stanfiel, D.P., 1964. Nigerian Tree 2 Department of Forest Research, lbadan P 101 - 192

Lewis, S.M., Bam, B.J., Bates, I., 2002. Dacie and Lewis Practical Haematology. ( $9^{\text {th }}$ ed.) Churchill Livingstone. Pp. $167-172$.

Loeb, S, Hamilton, H.K., Hubbard, J., Hard, M.H., Blake, G.J. and Beverly Lane M.D., 2005. Clinical laboratory test: Values and implication. Sprunghouse Corporation User. P. 29, 30, 36, 96.

Nelson, D.L. and Cox M.M., 2000. Lihninger principles of biochemistry $3^{\text {rd }}$ edn. P 413 .

Okwari, O. O., Offem, E. O., Onoriode, J. and Obembe, A. O., 2007. Antihistamenergic activity of African breadfruit seed diet on gastric acid secretion in rat. Global J. Pure and Applied Sciences. 13(1): 85 -88 .

Sembuligam, K. and Sembuligam, P., 2007. Essential of Medical Physiology. $4^{\text {th }}$ ed. JAYEE BROTHERS Medical Publishers, New Delhi. P. 642.

Stroeve, E. A. and Makarova, V.G., 1984. Laboratory Manual in Biochemistry. (Section on Liver Function). Moscow Milk Publishers. Pp 47.

Woodland, D. W., 1991.Contemporary plants systemic practice. Eaglewood, New Jessey. P. 167. 